\title{
A Short Review about Using MicroResp Method for the Assessment of Community Level Physiological Profile in Agricultural Soils
}

\author{
Bogdan-Mihai ONICA, Roxana VIDICAN*, Mignon SANDOR \\ University of Agricultural Sciences and Veterinary Medicine Cluj-Napoca, 3-5 Calea Manastur, 400372, Cluj-Napoca, Romania. \\ *corresponding author, e-mail: roxana.vidican@usamvcluj.ro
}

Bulletin USAMV series Agriculture 75(1)/2018

Print ISSN 1843-5246; Electronic ISSN 1843-5386

DOI 10.15835/buasvmcn-agr: 001817

\begin{abstract}
MicroResp is a colorimetric method developed by Campbell et al., (2003), used for assessing the community level physiological profile of the microbial population. MicroResp can be used to assess soil health, pollution induced community tolerance, also for toxicity testing, pesticide degradation profiles, bioremediation evaluation and water ecology and toxicity. The aim of the present review was to look over the results of recent papers and to highlight the importance and efficiency of the MicroResp method in assessing the physiological profile of the microbial community. The method advantages and limitations were also assessed. We focused on agricultural soil in order to deepen our understanding about changes of microbial community induced by agricultural practices. To achieve this goal, academic literature was analyzed using an academic database. There were set a total of six keywords, used to make a search algorithm, achieving five search terms. For each search, the first four articles of interest were chosen to be reviewed. After the searches for each of the terms, between 72 and 210 articles were found, 20 of them being chosen for final evaluation. Following the undertaken research, it can be stated that MicroResp method is an important tool to assess the physiological profile of the microbial community, featuring a series of advantages that place it ahead of other competing methods.
\end{abstract}

Keywords: Community level physiological profile, MicroResp, Soil, Functional diversity.

\section{Introduction}

Soil is an important resource which supports a large number of ecosystem goods and services from which humankind benefits (Laishram et al., 2012). Today soil face a large range of threats from human activities and global change like erosion, sealing, salinization, compaction, pollution with heavy metals, hydrocarbons and xenobiotics, loss of organic matter, atmospheric pollution, acidification and climate change (Chapman et al., 2007; Sassi et al., 2012).

In soil the microbial community plays an important role in decomposition and stabilization of organic matter as well in immobilization and mineralization of nutrients and presents a great diversity. It can also intervene in plant growth and nutrient uptake by releasing certain substances which can stimulate or inhibit, influencing root physiology and architecture (Bérard et al., 2012;
Vivian et al., 2013). There is little knowledge about the composition and diversity of microbial communities and how the microbiota can affect the fertility and productivity of the soil (Grayston et al., 2001). However, the microbial community composition depends primarily on the land-use, pH and soil organic matter (Creamer et al., 2016), plant species (Gartzia Bengoetxe et al., 2016) and also environment factors such as water regime can affect microbial activity (Pailler et al., 2014; Sandor et al., 2011).

One of the parameters used to assess the impact of land use in soil microbial community size, activity, composition and diversity is the soil microbial respiration, which can be used as indicator of soil fertility, which if drops indicates a decrease in soil quality and health (Burton et al., 2010). 


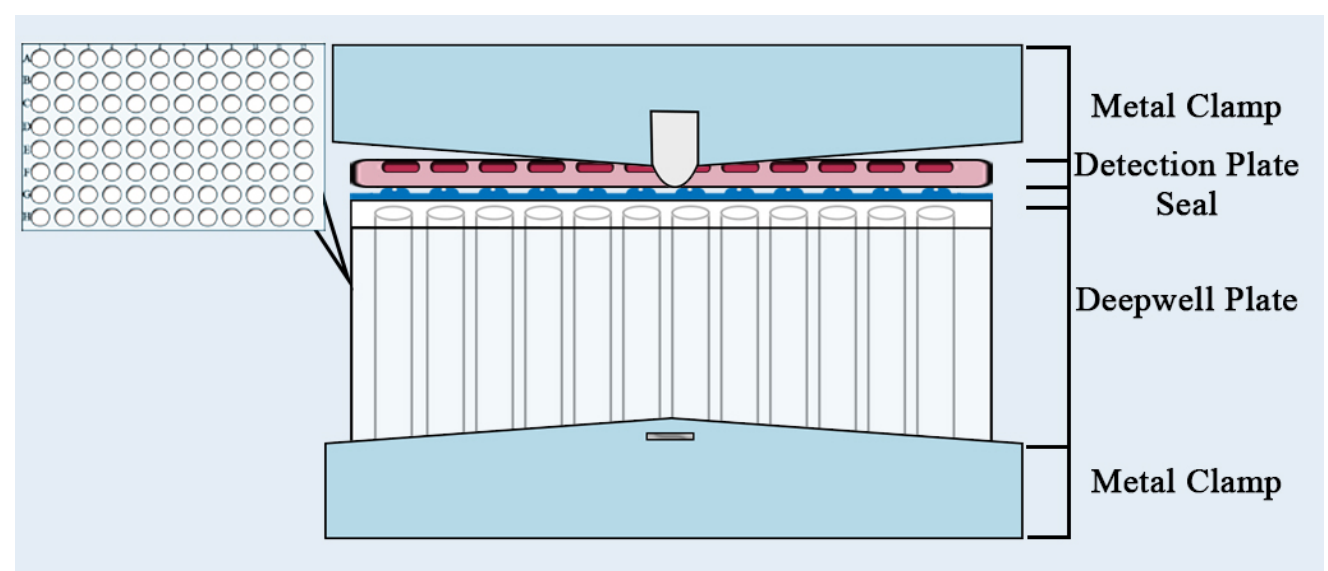

Figure 1. MicroResp system components

Table 1. Carbon sources used in MicroResp

\begin{tabular}{|c|c|c|c|c|}
\hline & & Carbon sources & & \\
\hline Carbohydrates & Carboxylic acids & Amino acids & Amino sugar & Phenolic acid \\
\hline D-trehalose & Citric Acid & L-arginine & \multirow{5}{*}{$\mathrm{N}$-acetylglucosamine } & \multirow{5}{*}{ Protocatechuic acid } \\
\hline D-galactose & L-malic acid & $\begin{array}{c}\gamma \text {-aminobutyric } \\
\text { acid }\end{array}$ & & \\
\hline L-arabinose & Oxalic Acid & L-lysine & & \\
\hline D-glucose & \multirow{2}{*}{$\alpha$ - ketoglutaric acid } & L-alanine & & \\
\hline D-fructose & & L-cysteine & & \\
\hline
\end{tabular}

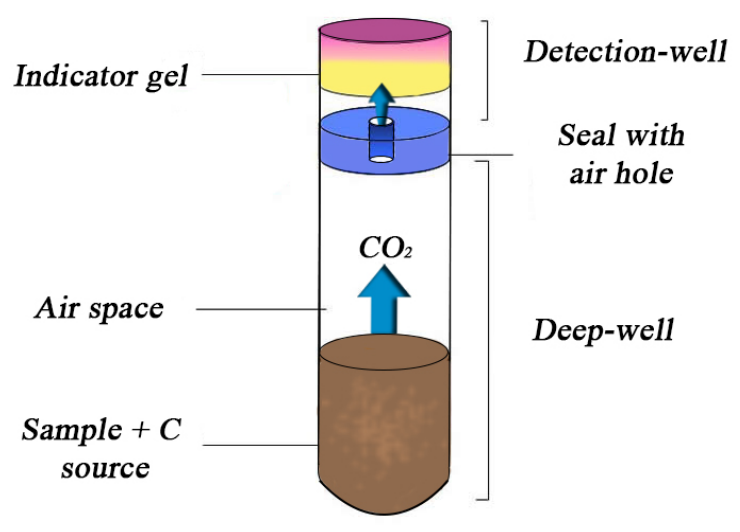

Figure 2. Deep-well and detection plate schematic working principle Source: (Campbell et al., 2003)

To assess soil respiration and community level physiological profile, MicroResp is a suitable method. MicroResp is a colorimetric whole soil method, based on 96-well microtitre plate and 16 carbon substrates which are used by the microbial community from the soil (Chapman et al., 2007).

The main objectives of this study were to assess the results of reviewed papers and the importance and efficiency of the MicroResp method in determining the physiological profile of the microbial community, its advantages and also its limitations.

\section{MicroResp Technique}

Soil microbial community and activity monitoring can be a powerful tool for understanding applied ecological context (Frąc et al., 2012). To assess the health and activity a basic parameter is the carbon dioxide level, which is released by the soil microbial community during 
Table 2. Search algorithm and results

\begin{tabular}{cccc}
\hline Number & Keywords & Total Results & Results of interest \\
\hline 1 & „Community level physiological profile“ AND & 89 & 4 \\
\hline 2 & Microresp AND Soil & 72 & 4 \\
\hline 3 & Microresp AND Soil And „Functional diversity“ & 210 & 4 \\
\hline 4 & Microresp AND Soil AND Fertilizer & 150 & 4 \\
\hline 5 & Microresp AND Soil AND Wheat & 136 & 4 \\
\hline
\end{tabular}

Table 3. Objectives and results of assessed studies about fertilizers and CLPP

\begin{tabular}{|c|c|c|c|}
\hline No. & $\begin{array}{l}\text { Objectives } \\
\end{array}$ & Results & Source \\
\hline 1 & $\begin{array}{l}\text { Effect of cattle manure with and without } \\
\text { biodynamic preparation in comparison } \\
\text { with mineral fertilization (+ straw } \\
\text { incorporation) on functional diversity of } \\
\text { the soil microbial community. }\end{array}$ & $\begin{array}{l}\text { Carbon source catabolic profile was clearly different } \\
\text { between cattle manure treatments and those with mineral } \\
\text { treatments, the discrimination was mainly based on amino } \\
\text { acids and neutral sugars. }\end{array}$ & $\begin{array}{c}\text { Sradnick et al., } \\
2013\end{array}$ \\
\hline 2 & $\begin{array}{l}\text { Assess the genetic composition of fungal } \\
\text { community by molecular tools and the } \\
\text { functional diversity of soil microbial } \\
\text { community by MicroResp in poplar } \\
\text { plantations grown under elevated } \mathrm{CO}_{2} \\
\text { with or without fertilization. }\end{array}$ & $\begin{array}{l}\text { The microbial catabolic activity was directly influenced by } \\
\text { the soil nutrient availability and plant inputs, and the poplar } \\
\text { species significantly affected } \mathrm{C} \text { utilization rates. They found } \\
\text { higher utilization rates of } \mathrm{C} \text { compounds in soils without } \mathrm{N} \\
\text { limitation, and under elevated [CO2], there was a decrease } \\
\text { of microbial catabolic activity in N limited soils whereas in } \\
\text { fertilized soils the substrate utilization was enhanced, in } \\
\text { particular in } P . \text { alba and } P \text {. nigra. }\end{array}$ & $\begin{array}{l}\text { Lagomarsino } \\
\text { et al., } 2007\end{array}$ \\
\hline
\end{tabular}

Table 4. Objectives and results of assessed studies about pollution and CLPP

\begin{tabular}{|c|c|c|c|}
\hline No. & Objectives & Results & Source \\
\hline 1 & $\begin{array}{l}\text { Development and evaluation of a } \\
\text { MicroResp-based method which can } \\
\text { be used as an ecotoxicological assay to } \\
\text { measure the impact of metals, namely } \\
\text { copper (Cu), on soil function. }\end{array}$ & $\begin{array}{l}\text { The MicroResp assay can be simply modified to assess } \\
\text { the ecotoxicology of soil contaminants, such as metals, on soil } \\
\text { catabolic function. The modified process includes experimentally } \\
\text { determined soil moisture assessment for optimum microbial } \\
\text { activity. Contaminants are mixed into soil samples at a range of } \\
\text { concentrations, each sample is then dispensed into a column of } \\
\text { eight wells in } 96 \text { well format (deep) plates. Moisture and glucose } \\
\text { are added to the samples at levels to provide maximum response, } \\
\text { and released } \mathrm{CO}_{2} \text { is measured. }\end{array}$ & $\begin{array}{l}\text { Wakelin et } \\
\text { al., } 2013\end{array}$ \\
\hline 2 & $\begin{array}{l}\text { Assess SIR, CLPP and PICT using } \\
\text { the MicroResp method to characterize } \\
\text { microbial communities after exposure } \\
\text { to environmental concentrations of } \\
\text { metals in a long-term field study. }\end{array}$ & $\begin{array}{l}\text { MicroResp can be used in PICT-bioassays to assess heavy } \\
\text { metal (Cd) impact to soil microbial communities. Dose response } \\
\text { curves for soil Cd and soil microbial glucose mineralization } \\
\text { were obtained on microrespirometric ecotoxicological bioassays } \\
\text { with Cd, making it possible to calculate half maximal effective } \\
\text { concentration }\left(\mathrm{EC}_{50}\right) \text {. } \mathrm{EC}_{50} \text { values were positively correlated with } \\
\text { Cd concentrations in soil plots. }\end{array}$ & $\begin{array}{c}\text { Bérard et al., } \\
2014\end{array}$ \\
\hline 3 & $\begin{array}{l}\text { Developed a protocol based on the } \\
\text { substrate-induced respiration of a river } \\
\text { biofilm community, using the Micro- } \\
\text { Resp technique, in a pollution-induced } \\
\text { community tolerance approach }\end{array}$ & $\begin{array}{l}\text { The results show that MicroResp can be used in bioassays to as- } \\
\text { sess the toxicity toward biofilm communities of a wide range of } \\
\text { metals }(\mathrm{Cu}, \mathrm{Zn}, \mathrm{Cd}, \mathrm{Ag}, \mathrm{Ni}, \mathrm{Fe}, \mathrm{Co}, \mathrm{Al} \text { and } \mathrm{As} \text { ). Moreover, a com- } \\
\text { munity-level physiological profile based on the mineralization of } \\
\text { different carbon substrates was established. }\end{array}$ & $\begin{array}{l}\text { Tlili et al., } \\
2011\end{array}$ \\
\hline
\end{tabular}

decomposition of carbon substrates (Campbell et al., 2003).

A method which can be used to assess the soil microbial community is MicroResp which is a colorimetric technique that allows the measurement of $\mathrm{CO}_{2}$ from whole soil resulting from the utilization of different carbon sources by the microbial population (Sassi et al., 2012). However, MicroResp consists of two microtiter plates placed face to face, one is the deep-well plate and the other is the detection plate (Campbell et al., 2003). In the deep-well plate soil samples and carbon 
Table 5. Objectives and results of assessed studies about crops and CLPP

\begin{tabular}{|c|c|c|c|}
\hline No. & Objectives & Results & Source \\
\hline 1 & $\begin{array}{l}\text { Assess the effects on soil labile organic } \\
\mathrm{C} \text { and } \mathrm{N} \text { pools and microbial metabolic } \\
\text { profiles and diversity in temperate } \\
\text { climate with treatments of winter cover } \\
\text { crops. }\end{array}$ & $\begin{array}{l}\text { Growth of winter crops increased soil labile organic matter and micro- } \\
\text { bial metabolic diversity compared with the control. There are no differ- } \\
\text { ences in labile organic matter between the legume crops and non-legume } \\
\text { crops. Legume crops had lower SIR and higher } \mathrm{H} \text { than non-legume } \\
\text { crops. The microbial metabolic profiles are different under crop treat- } \\
\text { ments against those of control. Moisture, } \mathrm{pH} \text {, crop biomass and extract- } \\
\text { able organic N were the most important factors in determining pattern } \\
\text { of the microbial metabolic profiles. }\end{array}$ & $\begin{array}{l}\text { Zhou et al., } \\
2012\end{array}$ \\
\hline 2 & $\begin{array}{l}\text { This study used soil microcosms to } \\
\text { investigate the impact of water status } \\
\text { (saturated and non saturated) and } \\
\text { straw application ( } 10 \mathrm{~g} \mathrm{~kg}^{-1} \text { soil) on } \\
\text { soil microbial composition and activity } \\
\text { (MicroResp }{ }^{\text {Tax }} \text { method). }\end{array}$ & $\begin{array}{l}\text { Results suggest that (1) the size of microbial communities in paddy } \\
\text { soil is more limited by carbon substrate availability rather than by the } \\
\text { anaerobic conditions due to waterlogging and (2) that soil water status is } \\
\text { more important as a control of fungal growth and microbial community } \\
\text { activity. }\end{array}$ & $\begin{array}{l}\text { Pan et al., } \\
2015\end{array}$ \\
\hline
\end{tabular}

Table 6. Objectives and results of assessed studies about forest soils and CLPP

\begin{tabular}{|c|c|c|c|}
\hline No. & Objectives & Results & Source \\
\hline 1 & $\begin{array}{c}\text { Assess the changes of microbial functional } \\
\text { diversity and other soil chemical and } \\
\text { biochemical properties following forest } \\
\text { coppicing. }\end{array}$ & $\begin{array}{l}\text { Enzyme activities and CLPP increased in coppiced plots } \\
\text { indicating higher decomposition processes promoted by } \\
\text { plant debris and rhizodepositions released after cutting. }\end{array}$ & $\begin{array}{c}\text { Pignataro et } \\
\text { al., } 2012\end{array}$ \\
\hline 2 & $\begin{array}{l}\text { 1. compare the ability of the Degens and } \\
\text { Harris approach and the MicroResp }{ }^{\mathrm{TM}} \\
\text { approach to distinguish between soils from } \\
\text { previously mined (rehabilitated) and non- } \\
\text { mined Western Australian forest ecosystems. } \\
\text { 2. assess the similarity in CLPP profiles } \\
\text { between 3- and 16-year-old forest } \\
\text { rehabilitation (mound and furrow) and } \\
\text { adjacent non-mined forest soil. }\end{array}$ & $\begin{array}{l}\text { Results suggest that the aspect of microbial heterotrophic } \\
\text { function measured in this study takes up to } 3 \text { years to } \\
\text { re-establish in the furrows and between } 3-16 \text { years in the } \\
\text { mounds of post-mined rehabilitation soils. Results also } \\
\text { indicated that the MicroResp }{ }^{\mathrm{TM}} \text { was substantially better } \\
\text { than the Degens and Harris approach in distinguishing } \\
\text { between treatments, this is likely to be due to differences } \\
\text { in substrate concentrations and soil water potentials } \\
\text { between approaches. }\end{array}$ & $\begin{array}{l}\text { Lalor et al., } \\
\quad 2007\end{array}$ \\
\hline 3 & $\begin{array}{c}\text { Explore the effects of repeated burning on } \\
\text { the broader soil microbial community and } \\
\text { determine if the changes observed were } \\
\text { also associated with changes in functional } \\
\text { diversity. }\end{array}$ & $\begin{array}{l}\text { Microbial biomass in the } 2 \text { year burn treatments was } 50 \% \\
\text { less than both the control and } 4 \text {-year burn treatments. } \\
\text { There was also concomitantly less respiratory activity } \\
\text { which mirrored the known changes in soil C and substrate } \\
\text { quality. The short term ( } 6 \text { h) SIR of arginine, lysine, } \\
\text { galactose and trehalose were significantly inhibited in } \\
\text { the } 2 \text { year burn soils. The data suggest that a } 4 \text {-year } \\
\text { burn is a more sustainable practice for maintaining the } \\
\text { original structure and function of the forest belowground } \\
\text { ecosystem. }\end{array}$ & $\begin{array}{l}\text { Campbell et } \\
\text { al., } 2008\end{array}$ \\
\hline 4 & $\begin{array}{l}\text { The aim of this study was to determine } \\
\text { which substrates provided the highest } \\
\text { discriminatory power for the CLPP assay; } \\
\text { either individually or grouped into functional } \\
\text { types. }\end{array}$ & $\begin{array}{l}\text { Differences in soil CLPP between rehabilitation and } \\
\text { non-mined forest soils were found to persist (up to } 26 \\
\text { years post-mining) despite recovery of total microbial } \\
\text { respiratory activity. The proportional response to complex } \\
\text { substrates was consistently lower in rehabilitation than } \\
\text { non-mined forest soil, suggesting a decreased functional } \\
\text { diversity. Differences in CLPP between rehabilitation and } \\
\text { non-mined forest soils were also due to variable responses } \\
\text { to several carboxylic acids. Prescribed burning did not } \\
\text { influence soil CLPP. }\end{array}$ & $\begin{array}{l}\text { Banning et } \\
\text { al., } 2012\end{array}$ \\
\hline
\end{tabular}

sources are inserted, and the detection plate is a system which detects the evolved carbon dioxide using cresol as an indicator (Campbell et al., 2003). The carbon sources used in MicroResp method are
16 and were selected to be ecologically relevant to soil and to be able to dissolve in water (Table 1).

The two plates are sealed face to face using a silicone rubber such that each well from the deep-well plate communicates with one from the 
detection plate and is held together firmly with a metal clamp like in Fig. 1 (Chapman et al., 2007).

The principle of indicator gel from detection plate is based on the chemical formula: $\mathrm{CO}_{2}+\mathrm{H}_{2} \mathrm{O}+\mathrm{HCO}_{3}^{-} \rightarrow 2 \mathrm{CO}_{3}^{-}+3 \mathrm{H}^{+}$

Cresol indicator changes its color from pink to yellow with decreasing $\mathrm{pH}$ of the gel. The advantage of this method is that the indicator is not in direct contact with the sample (Drage et al., 2012).

\section{Materials and methods}

In order to make this review Google Scholar scientific database was used, which is an academic web search engine released in 2004, that indexes

Table 7. Objectives and results of assessed studies about CLPP

\begin{tabular}{|c|c|c|c|}
\hline No. & Objectives & Results & Source \\
\hline 1 & $\begin{array}{l}\text { 1. to determine } \mathrm{C} \text { saturation concentrations } \\
\text { with the MicroResp method by testing a } \\
\text { gradient of C additions with a wide range of } \\
\text { substrates. } \\
\text { 2. to evaluate the potential influence of the } \\
\text { amount of SOC on this threshold. }\end{array}$ & $\begin{array}{l}\text { The soil organic carbon (SOC), total activity and catabolic } \\
\text { evenness were similar for C substrate addition above } 10 \% \mathrm{C} \\
\text { added of SOC, suggesting microbial respiratory metabolism } \\
\text { saturation. Below this threshold, CLPP were significantly } \\
\text { altered, especially when the amount of SOC was low. This } \\
\text { threshold corresponded to } 4 \text { up to } 10 \mathrm{mgC} \mathrm{mL}^{-1} \text { soil water } \\
\text { which is } 66-87 \% \text { lower than used in the original approach. }\end{array}$ & $\begin{array}{l}\text { Lerch et al., } \\
\quad 2013\end{array}$ \\
\hline 2 & $\begin{array}{l}\text { It was investigated the relationship between } \\
\text { soil physicochemical properties of microbial } \\
\text { community structures (bacterial and fungal) } \\
\text { and catabolic function. }\end{array}$ & $\begin{array}{l}\text { Soil pH was identified as the key habitat-selective } \\
\text { physicochemical soil property associated with variation } \\
\text { in biological diversity and profiles of organic substrate } \\
\text { utilization. With decreasing pH, the catabolism of common } \\
\text { low molecular weight organic compounds (especially cysteine } \\
\text { and aspartic acid) declined, however catabolism of two others } \\
\text { (lysine and arginine) increased. The genetic structure of the } \\
\text { bacterial communities in soil strongly correlated with pH and } \\
\text { that of soil fungi with pH and sand percent. }\end{array}$ & $\begin{array}{c}\text { Wakelin et } \\
\text { al., } 2008\end{array}$ \\
\hline 3 & $\begin{array}{l}\text { Determine the impacts of sample storage on } \\
\text { microbial activity and community structure } \\
\text { in paddy field soil. }\end{array}$ & $\begin{array}{l}\text { Basal respiration was unusually increased in the drained soil } \\
\text { after storage, but recovered after a } 7 \text {-day re-incubation. In } \\
\text { contrast, the impact on flooded soils was minimal. Further, the } \\
\text { soil community-level physiological profile (CLPP) was affected } \\
\text { by storage, but microbial community structure remained } \\
\text { mostly unchanged. Sequencing also showed that } \alpha \text { diversity of } \\
\text { the flooded paddy soil was higher than that in the drained soil. }\end{array}$ & $\begin{array}{l}\text { Wang et al., } \\
2014\end{array}$ \\
\hline 4 & $\begin{array}{l}\text { 1. compare soil microbial biomass, activity } \\
\text { and community structure in vegetable } \\
\text { systems between greenhouse and open field } \\
\text { conditions under both conventional and } \\
\text { organic management strategies. } \\
\text { 2. determine whether soil chemical } \\
\text { parameters and microbial properties were } \\
\text { correlated. }\end{array}$ & $\begin{array}{c}\text { Four treatments were examined and the impact on soils and } \\
\text { their microbial communities: }(1) \\
\text { organic management in greenhouses (Or-Gr) and (2) } \\
\text { open fields (Or-Op) and (3) conventional management in } \\
\text { greenhouses (Co-Gr) and (4) open fields (Co-Op). Or-Gr had } \\
\text { significantly higher total, bacterial (both Gram-positive and } \\
\text { negative), and fungal PLFA concentrations (P < 0.05) than the } \\
\text { other treatments. Generally, soil quality followed the series } \\
\text { Or-Gr > Or-Op > Co-Gr > Co-Op. Organic and greenhouse } \\
\text { management had a significant interaction effect. Findings } \\
\text { suggest that greenhouse management should be promoted for } \\
\text { food security. }\end{array}$ & $\begin{array}{c}\text { Ge et al., } \\
2013\end{array}$ \\
\hline 5 & $\begin{array}{l}\text { Investigate the potentially ameliorative } \\
\text { effects of lime, charcoal, and urea additions } \\
\text { on soil nitrification and carbon substrate } \\
\text { utilization (using the } \\
\text { MicroResp method). }\end{array}$ & $\begin{array}{l}\text { Multivariate analysis of the } \mathrm{C} \text { source utilization data revealed } \\
\text { that lime altered } \mathrm{C} \text { substrate utilization more than urea or } \\
\text { charcoal in these highly acidic soils. Results suggest that } \\
\text { acidtolerant nitrifiers do exist in these soils and have potential } \\
\text { for high activity, and pH (lime addition) and N-substrate (urea) } \\
\text { most often increased nitrification. However, no single factor } \\
\text { controlled nitrification in every soil, suggesting an interaction } \\
\text { between abiotic and nitrifier community composition as a } \\
\text { result of land use and soil type interactions. }\end{array}$ & $\begin{array}{c}\text { Yao et al., } \\
2011\end{array}$ \\
\hline 6 & $\begin{array}{l}\text { Identify possible impacts of timing and the } \\
\text { type of tillage implement used in a strategic } \\
\text { tillage (ST) on a long-term no-till (NT) farm } \\
\text { with regards to soil productivity, physical, } \\
\text { chemical and biological properties. }\end{array}$ & $\begin{array}{l}\text { ST with either a chisel cultivator or a disc chain has great } \\
\text { potential to assist in weed management as it did not } \\
\text { statistically influence crop productivity or the physical, } \\
\text { chemical and biological properties of the soil, regardless of the } \\
\text { tillage timing. Further research is needed. }\end{array}$ & $\begin{array}{c}\text { Liu et al., } \\
2016 \text { a }\end{array}$ \\
\hline
\end{tabular}




\begin{tabular}{|c|c|c|c|}
\hline No. & Objectives & Results & Source \\
\hline 7 & $\begin{array}{l}\text { Examine the influence of chisel and offset } \\
\text { disc tillage on soil microbial properties of } \\
\text { this long-term no-till (NT) Calcisol. }\end{array}$ & $\begin{array}{l}\text { Relative to the NT, chisel tillage led to significant increases } \\
\text { in microbial biomass carbon }(+34.4 \%) \text {, abundances of } \\
\text { Alphaproteobacteria }(+74.6 \%) \text {, Bacteroidetes }(+113.7 \%) \\
\text { and Firmicutes }(+36.5 \%) \text {, and the utilization of D+ cellubiose } \\
(+178.4 \%) \text { as well as mannitol }(+167.2 \%) \text { at } 0-10 \mathrm{~cm} \text { depth. } \\
\text { In contrast, the influence of offset disc tillage was restricted to } \\
\text { an increased abundance of Alphaproteobacteria }(+64.6 \%) \text { at } \\
0-10 \mathrm{~cm} \text { depth. Overall, one-time strategic tillage using either } \\
\text { chisel or offset disc had a minor positive influence on soil } \\
\text { biological attributes of the NT Calcisol } 13 \text { months after tillage. }\end{array}$ & $\begin{array}{l}\text { Liu et al., } \\
2016 \text { b }\end{array}$ \\
\hline 8 & $\begin{array}{l}\text { 1. to determine the distribution of organic } \\
\text { matter, microbial functions and diversity in } \\
\text { soil and physically isolated fractions. } \\
\text { 2. to determine how soil microbial } \\
\text { functions and diversity were related to the } \\
\text { accessibility and decomposability of organic } \\
\text { C pool at the small scale. }\end{array}$ & $\begin{array}{l}\text { Organic C availability drove microbial activity and functional } \\
\text { diversity in particle and aggregate-size fractions, with the } \\
\text { highest degree of soil functioning potential found in soils } \\
\text { with the largest amount of organic matter. This pattern was } \\
\text { dependent on the organic matter quality and accessibility, as } \\
\text { well as microbial selection and distribution. Fine fractions, } \\
\text { micro-aggregates and free particulate organic matter (F-POM) } \\
\text { resulted to have specific physical and chemical characteristics, } \\
\text { which induced a high degree of functional diversity. }\end{array}$ & $\begin{array}{c}\text { Lagomarsino } \\
\text { et al., } 2012\end{array}$ \\
\hline 9 & $\begin{array}{l}\text { 1. assess if commonly used restoration } \\
\text { treatments (hydroseeding, fertilization and } \\
\text { irrigation) affect soil microbial functional } \\
\text { diversity and processes related to soil } \\
\text { functioning (basal respiration, total } \mathrm{N} \text { and } \mathrm{P} \\
\text { and in situ } \mathrm{N} \text { availability rate). } \\
\text { 2. assess what portion of plant effects on } \\
\text { processes related to soil functioning is } \\
\text { mediated indirectly by microbial functional } \\
\text { diversity. }\end{array}$ & $\begin{array}{l}\text { Results indicate that the restoration of recently built slopes } \\
\text { can potentially be improved with treatments that promote } \\
\text { plant compositional shifts, such as fertilization, or alter soil } \\
\text { function, such as the enhancement of soil microbial functional } \\
\text { diversity. They also highlight that plant-soil interactions are } \\
\text { an important process that can be manipulated for restoration } \\
\text { purposes in early-successional stages, especially in nutrient- } \\
\text { poor semi-arid ecosystems. }\end{array}$ & $\begin{array}{l}\text { Pablo et al., } \\
2011\end{array}$ \\
\hline
\end{tabular}

academic journals, conference paper, books, dissertations, theses, abstracts and other academic literature.

Study selection was accomplished in two stages, firstly a number of seven keywords were set and used to make a search algorithm (Table 2). In the second stage of literature screening the search was made in the Google Scholar database using the five search algorithm set at the first stage and then, for each search algorithm, four relevant articles were set for inclusion.

Further, for inclusion of studies for data extraction, the screened studies had to assess microbial community from soil using as an indicator the soil respiration, which was assessed by MicroResp method, the article had to be written in English and the article should not be older than ten years.

\section{Results and discussion}

Table 2 presents the five search terms and the number of output results in the academic database.
Twenty studies were selected for data extraction and after analysis were divided into five categories:

- CLPP and fertilizers;

- CLPP and pollution;

- CLPP and crops;

- analysis of CLPP in forest soils;

- other studies to understand CLPP in soil

Table 3 presents the objectives and results for reviewed papers which assess the interaction between CLPP and fertilizers.

Table 4 presents the objectives and results for reviewed papers which assess the interaction between CLPP and pollution.

Table 5 presents the objectives and results for reviewed papers which assess the interaction between CLPP and crops.

Table 6 presents the objectives and results for reviewed papers which assess the CLPP in forest soils.

Table 7 presents the objectives and the results for reviewed papers which assess other ways to understand CLPP in soils. 


\section{Conclusions}

Soil health is important for humanity because supports a large number of ecosystem goods and services. One way to maintain soil health is to study soil microbial community which is an indicator of soil wellness.

MicroResp is a method which can be used in range studies for understanding soil microbial community like studies on the effect of pollution on the community, effect of fertilizers, effect of plant or other treatments and soil management. However, this method can be used as it is or with small modifications which are more relevant for the aim of the research, like using other carbon sources.

After reviewing all the studies can be affirmed that MicroResp is an appropriate method, rapid and sensitive for determination of microbial community functional diversity.

Acknowledgements: This work was supported by a grant of the Romanian National Authority for Scientific ResearchandInnovation, CNCS - UEFISCDI, project number PN-II-RU-TE-2014-4-2490

\section{References}

1. Banning NC. Lalor BM, Cookson WR, Grigg AH, Murphy DV (2012). Analysis of soil microbial community level physiological profiles in native and post-mining rehabilitation forest: Which substrates discriminate?, Applied Soil Ecology 56, 27-34.

2. Bérard A, Mazzia C, Valérie SD, Capowiez L, Capowiez Y (2014). Use of the MicroResp ${ }^{\mathrm{TM}}$ method to assess Pollution-Induced Community Tolerance in the context of metal soil contamination, Ecological Indicators 40, 27-33.

3. Bérard A, Sassi MB, Renault P, Gros R (2012), Severe drought-induced community tolerance to heat wave. An experimental study on soil microbial processes, J Soils Sediments, 12:513-518.

4. Burton J, Chen C, Xu Z, Ghadiri H, (2010), Soil microbial biomass, activity and community composition in adjacent native and plantation forests of subtropical Australia, J Soils Sediments, 10:1267-1277.

5. Campbell CD, Cameron CM, Bastias BA, Chen C, Cairney JWG (2008). Long term repeated burning in a wet sclerophyll forest reduces fungal and bacterial biomass and responses to carbon substrates, Soil Biology \& Biochemistry 40, 2246-2252.

6. Campbell CD, Chapman SJ, Cameron CM, Davidson MS, Potts JM (2003). A Rapid Microtiter Plate Method To Measure Carbon Dioxide Evolved from Carbon Substrate Amendments so as To Determine the Physiological Profiles of Soil Microbial Communities by Using Whole Soil, Applied and Environmental Microbiology, p. 35933599.
7. Chapman SJ, Campbell CD, Rebekka RE., (2007). Assessing CLPPs using MicroResp ${ }^{\mathrm{TM}}$, a comparison with Biolog and multi-SIR, J Soils Sediments 7 (6): 406-410.

8. Creamer RE, Stone D, Berry P, Kuiper I (2016), Measuring respiration profiles of soil microbial communities across Europe using MicroResp ${ }^{\mathrm{TM}}$ method, Applied Soil Ecology 97: 36-43.

9. Drage S, Engelmeier D, Bachmann G, Sessitsch A, Mitter B, Hadacek F (2012). Combining microdilution with MicroResp ${ }^{\mathrm{TM}}$ : Microbial substrate utilization, antimicrobial susceptibility and respiration, Journal of Microbiological Methods 88: 399-412.

10. Frąc M, Oszust K, Lipiec J (2012). Community Level Physiological Profiles (CLPP), Characterization and Microbial Activity of Soil Amended with Dairy Sewage Sludge, Sensors, 12, 3253-3268; doi:10.3390/ s120303253.

11. Gartzia-Bengoetxe N, Kandeler E, Martínez de Arano I, Arias-González A (2016). Soil microbial functional activity is governed by a combination of tree species composition and soil properties in temperate forests, Applied Soil Ecology, 100: 57-64.

12. Ge T, Chen X, Yuan H, Li B, Zhu H, Peng P, Li K, Jones DL, $\mathrm{Wu}$ J (2013). Microbial biomass, activity, and community structure in horticultural soils under conventional and organic management strategies, European Journal of Soil Biology xxx: 1-7.

13. Grayston S., Griffith GS, Mawdsley JL, Campbell CD, Bardgett RD (2001). Accounting for variability in soil microbial communities of temperate upland grassland ecosystems, Soil Biol. Biochem, 33: 533-551.

14. Lagomarsino A, Grego S, Kandeler E (2012). Soil organic carbon distribution drives microbial activity and functional diversity in particle and aggregate-size fractions, Pedobiologia 55, p 101-110.

15. Lagomarsino A, Knapp BA, Moscatelli MC, Angelis P, Grego S, Insam H (2007). Structural and Functional Diversity of Soil Microbes is Affected by Elevated [CO2] and N Addition in a Poplar Plantation, J Soils Sediments 7 (6): 399-405.

16. Laishram J, Saxena KG, Maikhuri RK, Rao KS (2012). Soil quality and soil health: a review, International Journal of Ecology and Environmental Sciences 38 (1): 19 - 37.

17. Lalor BM, Cookson WR, Murphy DV (2007). Comparison of two methods that assess soil community level physiological profiles in a forest ecosystem, Soil Biology \& Biochemistry 39: 454-462.

18. Lerch TZ, Coucheney E, Herrmann AM (2013). Sensitivity of soil microbial catabolic profiles to a gradient of carbon inputs: Does the soil organic matter matter?, Soil Biology \& Biochemistry 57: 911-915.

19. Liu H, Crawford M, Carvalhais LC, Dang YP, Dennis PG, Schenk PM (2016a). Strategic tillage on a Grey Vertosol after fifteen years of no-till management had no short-term impact on soil properties and agronomic productivity, Geoderma 267: 146-155.

20. Liu H, Carvalhais LC, Vivian RF, Crawford M, Dang YP, Dennis PG, Schenk PM,(2016b). One-time strategic tillage 
does not cause major impacts on soil microbial properties in a no-till Calcisol, Soil \& Tillage Research 158: 91-99.

21. Pablo GP, Bowker MA, Chapman SJ, Maestre FT, Soliveres S, Gallardo A, Valladares F, Guerrero C, Escudero A (2011). Early successional vegetation changes after roadside prairie restoration modify processes related with soil functioning by changing microbial functional diversity, Soil Biology \& Biochemistry 43: 1245-1253.

22. Pailler A, Vennetier M, Torre F, Ripert C, Guiral D (2014). Forest soil microbial functional patterns and response to a drought and warming event: Key role of climate -plant- soil interactions at a regional scale, Soil Biology \& Biochemistry 70: 1-4.

23. Pan F, Li Y, Chapman SJ, Yao H (2015). Effect of rice straw application on microbial community and activity in paddy soil under different water status, Environ Sci Pollut Res DOI 10.1007/s11356-015-5832-5.

24. Pignataro AM, Moscatelli C, Mocali S, Grego S, Benedetti A (2012). Assessment of soil microbial functional diversity in a coppiced forest system, Applied Soil Ecology 62: 115123.

25. Sandor MS, Brad T, Maxim A, Toader C (2011). the influence of selected meteorological factors on microbial biomass and mineralization of two organic fertilizers, Not Bot Hort Agrobot Cluj, 39(1): 107-113.

26. Sassi MB, Dollingera J, Renaulta P, Tlili A, Bérard A (2012). The FungiResp method: An application of the MicroRespTM method to assess fungi in microbial communities as soil biological indicators, Ecological Indicators 23: 482-490.

27. Sradnick A, Murugan R, Oltmanns M, Raupp J, Joergensen RG (2013). Changes in functional diversity of the soil microbial community in a heterogeneous sandy soil after long-term fertilization with cattle manure and mineral fertilizer, Applied Soil Ecology 63: 23-28.

28. Tlili A, Marechal M, Montuelle B, Volat B, Dorigo U, Bérard A (2011). Use of the MicroResp method to assess pollution-induced community tolerance to metals for lotic biofilms, Environmental Pollution 159: 18-24.

29. Vivian ARF, Carvalhais L, Schenk P (2013). Cultureindependent molecular tools for soil and rhizosphere microbiology, Diversity, 5, 581-612, doi:10.3390/ d5030581.

30. Wakelin S, Lombi E, Donner E, MacDonald L, Black A, O'Callaghan M (2013). Application of MicroResp for soil ecotoxicology, Environmental Pollution 179: 177-184.

31. Wakelin SA, Macdonald LM, Rogers SL, Gregg AL, Bolger T., Baldock JA (2008). Habitat selective factors influencing the structural composition and functional capacity of microbial communities in agricultural soils, Soil Biology \& Biochemistry 40: 803-813.

32. Wang J, Chapman SJ, Yao H (2014). The effect of storage on microbial activity and bacterial community structure of drained and flooded paddy soil, J Soils Sediments DOI 10.1007/s11368-014-1053-7.

33. Yao H, Campbell CD, Qiao X (2011), Soil pH controls nitrification and carbon substrate utilization more than urea or charcoal in some highly acidic soils, Biol Fertil Soils 47: 515-522.

34. Zhou X, Wu H, Koetz E, Xu Z, Chen C (2012). Soil labile carbon and nitrogen pools and microbial metabolic diversity under winter crops in an arid environment, Applied Soil Ecology 53: 49-55. 